UDC $327(71+4 \mathrm{CC})$

DOI https://doi.org/10.32837/apfs.v0i27.935

\author{
O. M. Antokhiv-Skolozdra \\ ORCID ID: https://orcid.org/0000-0003-4374-2541 \\ Candidate of Political Sciences, \\ Associate Professor at the Department of Foreign Languages \\ of the Faculty of International Relations \\ Ivan Franko National University of Lviv
}

\title{
CANADA-EU RELATIONS IN POLITICAL SPHERE
}

Introduction. The beginning of the XXI century was marked by the gradual resumption of cooperation between Canada and the European Union after a lengthy stagnation. After all, in the post-bipolar period, in Ottawa they focused predominantly on domestic issues. Furthermore, the United States established them as a key partner on the international arena, while Brussels, focused their efforts on building their own institutions and preparing for the EU enlargement. However, both sides were compelled to critically reconsider the state of bilateral relations and to seek mutually beneficial forms of cooperation.

Examining the relationship between Canada and the countries of United Europe, we should note their "exclusivity", since they are based on common goals and values. Canada has obtained a very positive image in Europe as a "friendly and noble nation" [1, p. 102] and an "honest broker and intermediary" [4, p. 157].

This stance distinguishes Canada significantly from the United States, which in the field of international relations is often viewed from the perspective of dominance. In terms of foreign policy, Ottawa's attempts to change its policy and distance itself from the United States are also worth noting.

Indeed, democratic dimension is an important pillar in the development of Canadian-European relations. In particular, Canadian troops have crossed the Atlantic twice in the last fifty years to stop totalitarianism and ensure democracy. Nowadays among Ottawa's merits are their efforts to achieve peace on the European continent and the deployment of unification processes.

Notwithstanding, experts emphasize that Canada might undergo changes that will reduce its European character. This may primarily happen due to demographic changes. New demographic groups in Canada may be more interested in closer relationship with their countries of origin rather than with Europe.

Regarding the peculiarities of approaches of Americans and Europeans to international problems, R. Kagan pointed out that they have radically different views of the world. In particular, he claimed that Europeans "came from Venus" because they try to resolve conflicts in a peaceful manner and seek compromises, while Americans are "from Mars" because they are rather willing to use force [8, p. 24].

Hence, Canadians also face the question of identifying their own approach in international politics. Some experts, as Kagan states, insist that Canadians be Americans and confess that they are adapting a "Martian" approach to international relations. However, according to Kagan's conclusions, Canadians are "closer to Venus" [8, p. 26]. Due to L. Exworthy, the nature of the attitude to the Canadian armed forces and their use, in particular, in peacekeeping operations, as well as their active participation in multilateral fora - indicate that Canada demonstrates a similar to European approach in international relations [10, p. 602].

Under these circumstances, we can identify different trends in relations between Canada and the $\mathrm{EU}$, but the major, in our opinion, is the increasing involvement of the EU member states' activity in various policy areas. This tendency is important for the EU-Canada relations, as it is an expression of Europeanized multilateralism, which affects Canada's relations with individual EU member states and generally affects global multilateralism $[4$, p. 35].

Problem stating. There are two conceptual orientations, distinguished in Canadian foreign policy after the end of World War II. On the one hand, Europe was viewed through the lens of economic interests, - initially as a commodity market and later as a source of investment. On the other hand, it concerned the strategic dimension of Canada's perception of Europe as the region, where its allies were located. Their independence and security, especially from a military point of view, were crucial to Canada's own security [9, p. 661].

By the end of the $1950 \mathrm{~s}$, Canada had been solely setting up its own representation of "economic" and "strategic" Europe, and its policy vectors in these two directions were complementary. Canada has successfully secured its own economic and security interests in the multilateral framework of Atlantics, enabling it not to be confined solely to its North American neighbor, the United States [9, p. 665]. In addition, these conceptual orientations of Canada's 
foreign policy towards Europe have had a direct impact on Canada's counterbalancing process with the United States.

Canada's sustainable development of its own format for interaction with European countries, especially in the light of integration processes, makes it essential to investigate attempts with the view to differentiating Canadian foreign policy in the context of finding alternatives to growing dependence on a neighboring US state.

Latest research analysis. Research conducted this century has shown that the academic field of study of Canada's Foreign Policy is characterized by theoretical pluralism. Canadian foreign policy has given impetus to the preparation and publication of a number of studies by K. Nossal, A. Cooper, T. Keating, J. Kirton, M. Hart, P. Hein and others. An important trend in the study of Canadian topics in Ukraine is the research of the Ukrainian community in Canada (Y. Balytska, A. Vasilenko, V. Makar, S. Fedunyak). Canada's foreign policy issues were raised by S. Kononenko, N. Ostash, and I. Cherchenko in their own works. At the same time, the focus of Canada's relations with the European Union hasn't been given enough attention by Ukrainian scientists.

The aim of the research is to describe the peculiarities of political dimension of Canada - EU cooperation with the account of the USA factor in transatlantic relations.

There are no significant misunderstandings in Canada-EU relations, except for a few cases of trade disputes. It should be emphasized that on many political issues, Canadian positions are closer to those of European countries than to the US positions. This, in particular, concerns domestic issues, immigration, regulation of the Internet, healthcare, etc. On international issues, Canada and the EU integrate common ground on the International Criminal Court, the Kyoto Protocol, nuclear non-proliferation, the fight against terrorism and others. As a result, closer cooperation between Canada and the EU is based on a mutual commitment to the implementation of the principles of democracy, market economy, the rule of law and multilateralism.

It's possible to distinguish various trends in the relationship between Canada and the EU, however, the main one, in our view, is to cover the increasing activity of the EU Member States in a growing number of political spheres. Under these conditions, the essential significance concerns Canada's ability to reach mutual understanding with the $\mathrm{EU}$, as it becomes the key player on the European continent, which necessitates the study of the political dimension of their interaction.

With the view of the fact, that at the current stage Canada should establish a systematic dialogue with both the EU institutions and Member States, so that the EU policy or its institutional component not lead to the neglect of the Canadian position or its interests in bilateral relations not be underestimated by the EU policy or its institutional components, we aim to find out the peculiarities of the political component of the relationship between Canada and the EU, taking into account its perspective dynamics.

Relations between Canada and the EU are bilateral, but they are developing in a broader international context. For countries such as Canada, an important aspect of activities in the international environment is consultation, cooperation and coordination with other countries.

Currently, the states of Europe are forming, to some extent, their own faction within NATO, the OSCE and other organizations. Their cooperation is becoming increasingly consistent, mostly EUfocused. Thus, in its European policy, Canada should pay attention not only to the EU, its institutions, but also to the relations between the Member States themselves, as well as the nature of the interaction of the Member States with the European institutions.

Initiatives such as the Common Foreign and Security Policy (CFSP) and others, indicate that a complex multi-level governance system involving institutions and Member States is being developed within the EU, which might have an impact on their relations with the third countries. In practice, this means that, even when it refers to the EU decision as a result of the coordination of positions within this association, it does not mean that the third countries will negotiate with only one institution, such as the European Commission, for instance [10, p. 601]. It should be emphasized that after concluding the Lisbon Treaty, the number of such institutions has increased.

However, from Canada's viewpoint, complexity and lack of clarity are not the biggest challenges in relations with theEU. More noticeable is the existence of a single European position in international forums, when it is first agreed among the EU Member States and only then with the third countries. Although it causes discontent of the United States or Japan, it can result in more serious consequences in the case of Canada, as it significantly reduces the importance of multilateralism and the potential for compromise, both globally and on the transatlantic level. Similarly, due to the EU's priority to internal issues, in foreign policy they will obviously focus on interaction with the key international players.

Conversely, the EU should not be seen as a homogeneous international actor, but rather as an institutional framework for solving a range of transatlantic issues, - from domestic to global ones. Herewith, bipolarity in transatlantic relations is gaining significance, which makes Canada dependent on the EU-US 
relations. In order to avoid possible "isolation" in transatlantic relations, Canada desired to conclude so-called "Mirror" agreements with the EU, which in fact duplicated agreements between the EU and the US. Meanwhile Ottawa's multilateralism initiative on the Transatlantic Free Trade Area ended to no avail, due to the lack of interest from both the US and the EU $[10, p .607]$, this does not mean that there are no issues of mutual interest between the parties. Bilateral cooperation between them is mainly carried out in a routine way through meetings of government officials, experts or representatives of certain interest groups. Issues of a commerce, human security, and global fight against terrorism, demographic changes, and immigration and refugee issues require constant exchange of information, coordination of positions. Thus, in the view of the Canadian side, relations with the EU should be conducted less on the traditional bilateral basis, but rather should create the necessary institutionalized frameworks for cooperation [10, p. 608].

Likewise, it should be borne in mind, that Canada is not a European country. Consequently, its membership in NATO, and to a less extent its involvement in the OSCE, has helped to avoid marginalization in international politics. However, from the perspective of the EU, Canada will remain a country from outside the European continent, so its position will have no impact on the political processes in the midst of this integration.

In compliance with the nature of European integration and the shared values that unite Canada with the countries of Europe, Canada-EU cooperation is expected to take place in narrow areas relevant to either a specific type of policy or common projects of global nature. It should be taken into consideration that the EU today goes beyond the traditional view of the Westphalian state [2, p. 12]. Subsequently, their relations will develop in a bureaucratic way and will be focused on solving narrow and specific tasks.

In the sphere of international relations Canada can be a valuable partner for the European Union, as in the case of its participation in the EU missions in Macedonia and Bosnia. Likewise, the country should strive to be involved in the preparation of important decisions of international concern in order to build common ground and to ensure a sufficient level of efforts coordination of the parties, ranging from regulating certain economic spheres to resisting the threat of space militarization.

In the opinion of Canadians, the $\mathrm{EU}$ is given the priority capacity as an important international economic player and a large attractive market, the potential of which has not been fully exploited by their entrepreneurs yet. Since the announcement of the "third alternative", the Government of Canada has sought to stimulate the more precise attention of their entrepreneurs to Europe by signing relevant agreements with the EU and seeking to conclude a multilateral or bilateral free trade agreement. In his view, this would help diversify Canada's international trade and reduce its dependence on the US. However, in accordance with the traditional perception of the Transatlantic Free Trade Area by Brussels as a problematic initiative, its creation may not have any prospects for implementation. Therefore, the two parties should focus on enhancing existing trade and economic relations.

Although the EU's political, economic and environmental experience is sometimes referred to as an example; it is not viewed as a social model for Canada. Also, the EU is not perceived as a role model for integration that can be reproduced in North America.

At the same time, the Canadian academic environment examines the activities of the EU supranational institutions in terms of using their experience in improving Canadian federalism. Moreover, in the security sphere, the EU has not been regarded as an effective mechanism to counter most challenges, with the exception of overcoming macroeconomic instability and coping with migration issues.

In compliance with the subject matter publications, Canadians, with few exceptions, do not see the EU as a counterpart to the United States. Europeans, like Americans, understand the meaning of "power" and the European Union is its embodiment. Therefore, Europeans are interested in cooperating with North American countries not only for increasing their influence, but also realizing that without legitimation of their own power this influence will be insignificant [9, p. 653].

This vision has resulted in Europeans being open to Canadians as an obvious and important international partner. In particular, from 1976 to 2004, a number of agreements were concluded with the view to promoting mutual trust and political and economic partnership between Canada and the states of Europe. For example, the 1976 Framework Agreement is the oldest formal agreement between the European Community and any industrialized country [5]. The Special Thematic Declaration (2004) recommended new steps aiming at closer cooperation. It emphasized that the EU and Canada share the fundamental values that are key to their development, and close cultural and historical ties and mutual respect for multilateralism are the cornerstones of their partnership [3].

On March 18, 2004, it was decided to strengthen bilateral commitments by concluding two agreements: the EU-Canada Partnership Agenda and the Enhanced Trade and Investment Agreement.

The EU-Canada Partnership Agenda prioritizes the intensification of political-level contacts in order to identify key policy issues and ways of their 
implementation. Although since 1976 there have been regular annual ministerial meetings, exchanges of views within the Special Joint Committees and periodic joint declarations, the two parties have set more ambitious goals. They can be grouped around five topics: providing international security and effective multilateralism; improving global economic development; boosting legal cooperation; enhancing cooperation in facing global and regional challenges; strengthening relations between EU and Canadian nations [3].

In order to improve coordination of the EU-Canada relations and to highlight the areas of cooperation, Canada and the EU have decided to continue holding top-level and ministerial dialogues on key global policy issues and other issues of mutual interest. In pursuant to facilitating the institutionalization of dialogue and cooperation, the parties have agreed to establish the EU-Canada Coordination Group with the view to prompt implementing decisions taken at the political level [7, p. 25]. The group was also called upon to monitor all aspects of bilateral relations and discussions between the EU and Canada, identify new areas of cooperation and prepare top-level and ministerial meetings.

Enhanced cooperation between the EU and Canada was envisaged in order to increase the effectiveness of multilateralism, in particular by involving UN efforts and developing initiatives based on common approaches in areas such as sustainable development, human rights protection, humanitarian aid and peacekeeping operations. In addition, the joint steps were envisaged to ensure the full jurisdiction of the International Criminal Court; prior coordination of parties' positions before international meetings, in particular, in the field of human rights and other humanitarian aspects; enhanced cooperation in international forums to assist the development of backward and developing countries [7, p. 25].

Furthermore, after decades of focusing on internal affairs, there has been a revision of Canada's foreign and defense policy, which has declared a desire to strengthen its presence in international relations. In particular, in his 2005 speech on foreign policy, Canadian Prime Minister P. Martin said: "Today's world is undergoing a profound transformation. <...> In this new world, such independent states as Canada - countries with small populations - run the risk of being marginalized as their influence diminishes and their competitiveness is threatened" [11, p. 2]. Therefore, in the belief of the Prime Minister, Canada needs partners and political mechanisms through which it can multiply its influence in the world [9, p. 651].

Recognizing the potential for further strengthening of political cooperation between Canada and the EU, the European Union has proposed to open negotiations on a framework political agreement that would facilitate cooperation in the future. Therefore, in September 2011, the relevant negotiations on the EU-Canada Strategic Partnership Agreement began. The agreement is based on the common values and principles of international peace and security, democracy, human rights, the rule of law and sustainable development. It identifies the areas and mechanisms for strengthening bilateral dialogue, cooperation and coordination with a view to realizing shared values [16, p. 147].

Particularly, it includes strengthening cooperation and coordination of activities in multilateral forums such as the UN, launching the dialogue on new issues to facilitate development assistance, and enhancing the role of the Joint Cooperation Committee, which should facilitate the relationship between Canada and the EU.

Taking into consideration that this agreement should serve as the basis for political cooperation between Canada and the EU in the future, sufficiently well-considered provisions have been chosen. In particular, issues which would affect the jurisdiction of the provinces and local authorities have been removed. Also, in order to avoid duplication, the issues covered by existing agreements between Canada and the EU have not been taken into account.

The text was divided into five main chapters. The first one refers to the "foundations of cooperation", which sets out the key principles, values and goals of bilateral cooperation in the four areas as follows: human rights, fundamental freedoms, democracy, the rule of law; international peace and security and effective multilateralism; economic and sustainable development; justice, freedom and security.

Each chapter contains provisions describing the mechanisms that will be further used to enhance dialogue and coordinate efforts to promote shared values, including human rights, non-proliferation, ensuring macroeconomic stability, sustainable development, protecting the environment, combating terrorism and organized crime. Personal contacts, including the regular exchange of parliamentary delegations, will also be of particular importance.

Pursuant to common positions on most foreign policy issues, the basis of the treaty was agreed upon quite promptly. One of the problematic aspects was the issue of dispute resolution. Canada, in particular, proposed an approach that would provide adequate evidence and use of expert advice to resolve disputes in a proper and constructive manner.

On November 27, 2013, the European Parliament adopted a report containing recommendations to the Council of the EU, the European Commission and the External Action Service on negotiations with Canada on the Strategic Partnership Agreement. In particular, Article 4 states that human rights issues should be one of the key elements of an agreement 
that is of a framework nature for both parties and formalizes their relations as strategic partners. Today, the EU insists that all key agreements include provisions on human rights, the fight against the proliferation of weapons of mass destruction, etc., and demonstrates their reluctance to make concessions on these issues regarding Canada [11, p. 3]. At the same time, the EU wishes to avoid a situation in which possible exceptions for Canada would give rise to the desire of other, less democratic states to insist on a similar approach towards them by the EU.

In its turn, Canada refuses to sign the Strategic Partnership Agreement, which provides for the possibility of termination of the Comprehensive Trade and Economic Agreement (CTEA) provided one of the parties does not respect human rights or does not comply with the Non-proliferation mass destruction weapons [13, p. 98]. Ottawa emphasizes the potential for abuse in this regard in the event of trade disputes and considers the binding nature of an agreement of an economic nature to human rights issues as one that undermines state sovereignty.

Conclusions. In pursuance of our experience and shared values, Canada and Europe will continue mutual cooperation aimed at solving social issues and facing potential challenges. It concerns common position on peace and security; trade and economic development; Arctic cooperation; federalism; protection of quality of life (including environmental and social problems); the challenges of democracy, such as non-participation in political life and lack of trust in the authorities; immigration and ethnic diversity; protection of culture in the conditions of globalization [14, p. 42].

Broad and diverse prospects for Canada-EU cooperation are a promising area of study within political science, as they are related to important aspects of the activities and role of government players and interconnections in a fragmented and globalized world. The dynamics of its international political development will continue to compel researchers to understand the accompanying processes and phenomena that will lead to a radical transformation of the modern international system.

\section{References}

1. Black D. Canada's Continuing Identity Crises. Foreign Affairs. 1995. Vol. 74. № 2. P. 99-115.

2. Caporaso J. The European Union and forms of state: Westphalian, regulatory or post-modern? Journal of Common Market Studies. 1996. Vol. 34. № 1. P. 56-63.

3. Canada-EU Partnership Agenda 2004. URL: http://www.canadainternational.gc.ca/eu-ue/ commerce_international/partnership-partenariat. aspx?lang=eng.

4. Cooper A. Canada-EU Relations in Comparative Perspective: Promise, Problems and Prospects. The European Community, Canada and 1992 / ed.
G. MacMillan. Calgary : The University of Calgary Press, 1994. P. 151-167.

5. Declaration on Canada-EU Relations. 18 March 2004 URL: http://eeas.europa.eu/canada/docs/2004 ottawa en.pdf.

6. Hawes M. Principal Power, Middle Power, or Satellite? Toronto : York Research Program in Strategic Studies, $1984.52 \mathrm{p}$.

7. Henriques K. This "New Europe“: Historic Policy Opportunities for Canada. Public Policy Paper 29. The Saskatchewan Institute of Public Policy. 2005. P. 22-31.

8. Kagan R. Power and weakness. Policy Review. 2002. June. P. 3-28.

9. Lindley-French J. Reconnecting Canada to the World (via Europe). International Journal. 2005. Vol. 60. No. 3. P. 651-665.

10.Long D. Transatlantic Relations and Canadian Foreign Policy. International Journal. 2003. Vol. 58. No 4. P. 591-614.

11. Martin P. Foreword from the prime minister: Making a difference. Canada's international policy statement. Ottawa, 2005. P. 2-5.

12. Molot M. Where Do We, Should We, or Can We Sit? A Review of Canadian Foreign Policy Literature. International Journal of Canadian Studies. 1990. № 1-2.

13. Nossal K.R. Home-grown IR: The Canadianization of international relations. Journal of Canadian Studies. 2016. Vol. 35. No. 1. P. 95-114.

14. Pentland Ch. L'option europ enne du Canada dans les ann es 80. tudes internationals. 1983. Vol. 14. No. 1. P. 39-58.

15. Pitts G. Storming the Fortress: How Canadian Business Can Conquer Europe in 1992. Toronto : Harper Collins, 1990. 213 p.

16. Potter E. Transatlantic Partners: Canadian Approaches to the European Union. Montreal and Kingston : McGill-Queen's University Press, 1999. 298 p.

17. Stairs D. Will and Circumstance and the Postwar Study of Canada's Foreign Policy. International Journal. 1995. Vol. 50. No. 1. P. 9-39.

\section{Summary}

Antokhiv-Skolozdra O. M. Canada-EU relations in political sphere. - Article.

The article considers the peculiarities of formation and development of relations between Canada and the European Union in political sphere. It points out that the common essence of approaches to modern international relations serves as a potential basis for building bilateral cooperation on the issues of establishing political cooperation. In the course of research on Canada's foreign policy it was noted that there is a number of features that are due to both internal context and external factors. In particular, it refers the peculiar nature of Canadian statehood, the existence of two linguistic communities, geographical location, and immediate neighborhood with the United States.

It emphasizes the similarity of Canada's positions with the approaches of European countries to solving a number of problems of modern world development. The importance of maintaining the transatlantic connection is among the significant issues. At the same time, it should be taken into account that there are peculiarities 
of establishing and maintaining relations between Canada and the European Union. On the one hand these are the relations with a strong multinational association and on the other - with each individual member state.

It is noted that, despite the long historical tradition in the relationship, the potential for cooperation between Canada and the EU is only partially used. It highlights the need for Canada to reach a new level in its relations with the European Union, provided that it maintains close relations with the United States of America. Areas of mutual interest, as well as problematic aspects of negotiations on a strategic partnership agreement between Canada and the European Union have been identified. Although Canada-EU relations are bilateral, they are evolving in a broader international context. It is analyzed that Canada can be a valuable partner for the European Union in the field of international relations. This country should strive to be involved in the preparation of important international decisions in order to build common positions and ensure a sufficient level of coordination between the parties.

Key words: Canada, European Union, political cooperation, bilateral relations, transatlantic cooperation, multilateralism.

\section{Анотація}

Антохів-Сколоздра О. М. Відносини Канади з Свропейським Союзом у політичній сфері. - Стаття.

У статті розглянуто особливості становлення та розвитку відносин між Канадою та Свропейським Союзом у політичній сфері. Зазначено, що нормативна спільність підходів до сучасних міжнародних відносин є потенційною основою для розбудови двосторонньої взаємодії з питань налагодження політичної співпраці.
Зазначено, що вивчення зовнішньої політики Канади вирізняється низкою особливостей, які обумовлені як внутрішнім контекстом, так і зовнішніми чинниками. Зокрема, йдеться про своєрідний характер канадського державотворення, наявність двох лінгвістичних спільнот, географічне положення, безпосереднє сусідство зі Сполученими Штатами.

Наголошено на збіжності позицій Канади з підходами держав Європи до вирішення низки проблем сучасного світового розвитку. Підкреслено важливість збереження трансатлантичного зв'язку. Водночас варто зважати на особливості побудови та підтримки відносин між Канадою та Європейським Союзом як із потужним багатонаціональним об'єднанням, так і з окремою державою-членом.

Зазначено, що, незважаючи на тривалу історичну традицію у відносинах, потенціал взаємодії Канади і ЄC використовується лише частково. Наголошено на необхідності для Канади виходу у взаєминах з Євросоюзом на новий рівень за умови збереження тісних відносин зі Сполученими Штатами Америки. Визначено сфери взаємного зацікавлення, а також проблемні аспекти перемовин щодо угоди про стратегічне партнерство Канади та Свропейського Союзу. Відносини між Канадою та ЄС є двосторонніми, однак вони розвиваються у ширшому міжнародному контексті. Доведено, що Канада у сфері міжнародних відносин може бути цінним партнером для Євросоюзу. Цій країні варто прагнути до залучення у процес підготовки важливих рішень міжнародного характеру для розбудови спільних позицій та забезпечення достатнього рівня координації зусиль сторін.

Ключові слова: Канада, Свропейський Союз, політична співпраця, двосторонні відносини, трансатлантична співпраця, мультилатералізм. 